\title{
Transnacionální praktiky, ,ancestral return' a adaptace rumunských Čechů přesídlených do Česka po roce 1989
}

\author{
Zdeněk Kresl - Tereza Freidingerová \\ DOI: 10.21104/CL.2016.2.04 \\ Transnational practices, ancestral return and adaptation \\ of Romanian Czechs resettled to Czechia after 1989
}

\begin{abstract}
The aim of the article is to examine the consequences of resettlement of Romanian Czechs from the Banat region to Czechia after 1989. Special emphasis is put on the role of various (individual, institutional) transnational practices and relations, migration networks and the Czech origin of returnees in their migrationdecision making and adaptation process. On the background of notions of 'ancestral return' or 'counter-diasporic migration', the study also discuss key questions whether the counter-diasporic migrants are rather returnees or the first migrant generation of Romanian Czechs, what the shared narratives of home are and how they, along with diasporic consciousness, affect migration of Romanian Czechs to the ancestral homeland. We argue that the experience with migration to the ancestral homeland exposes migrants to rethink their own identity as well as the relationship to a country of imagined exile and a country of imagined home. The study presents results of research conducted in Romania in 2012 and Czechia in 2013 and 2015 combining qualitative (monitoring, interviews with key informants, participant observation) and quantitative methods (questionnaire survey).
\end{abstract}

Keywords resettlement, Romanian Czechs, ancestral return, counterdiasporic migration, adaptation, transnational practices

Contact Mgr. Zdeněk Kresl, Přírodovědecká fakulta Univerzity Karlovy v Praze, katedra sociální geografie a regionálního rozvoje, Albertov 6, 12843 Praha 2, Czech Republic; e-mail: zdenek.kresl@seznam.cz

RNDr. Tereza Freidingerová, Ph.D., Metropolitní univerzita Praha, katedra asijských studií, Dubečská 900/10, 10031 Praha 10 - Strašnice, Czech Republic; e-mail: tereza.freidinger@gmail.com

Jak citovat / How to cite Kresl, Zdeněk - Freidingerová, Tereza. (2016). Transnacionální praktiky, ,ancestral return' a adaptace rumunských Čechů přesídlených do Česka po roce 1989. Český lid 103, 217-238. doi:http:// dx.doi.org/10.21104/CL.2016.2.04 


\section{Úvod $^{1}$}

Bígr, Eibentál, Gerník, Rovensko, Svatá Helena a Šumice - šest českých vesnic nacházejících se na jihozápadní hranici Rumunska v oblasti tzv. Banátu - dnes představují určité synonymum pro romantizující obraz českého krajana v dalekém, ekonomicky slabém regionu. Tedy obraz českého krajanarolníka, který žije těžký život - tradičním způsobem, mimo dosah moderních technologií a městského konzumního způsobu života - a který si i přes téměř dvě staletí od příchodu předků dokázal „zachovat svůj jazyk, kulturu, tradice a vztah ke své vlasti“, jak kladně hodnotí schopnosti krajanských komunit ve světě tehdejší předseda horní komory Parlamentu ČR Přemysl Sobotka ve své předmluvě k publikaci Nová emigrace z České republiky po roce 1989 a návratová politika (Sobotka 2014: 10).

Tato idealizující představa českých krajanů, mnohdy podporovaná folkloristickým, až stereotypizujícím přístupem médií k tématu, se realitě každým rokem více vzdaluje. Zatímco generace dnešních padesátníků a starších ji může naplňovat, mladší generace jsou mnohem blíže něčemu, co všeobecně přijímané mínění označuje pojmem „člověk 21. století“. Laické představy české společnosti o krajanech v Rumunsku také nezřídka implicitně předpokládají, že během desítek let života mimo zemi předků se komunity nijak zásadně kulturně, etnicky, jazykově ani mentalitou neproměnily a o příchodu potomků českých emigrantů se hovoří téměř výlučně rétorikou „návratu domů“. ${ }^{2}$ Do jaké míry je ale možné tento „návrat“ do země předků (,ancestoral return“) či kontradiasporickou migraci (,counter-diasporic migration") vnímat v kontextu - migračními studiemi obecně přijímaných - dualit „tady a tam“, „doma a v cizině“ či „být domácím a cizím“ (King - Christou 2010; Fortier 2000). Jsou tito diasporičtí navrátilci opravdu navrátilci, nebo první migrační generací rumunských Čechů? Je země jejich předků skutečným domovem, nebo jenom formou domova v podobě představovaného obrazu místa, který si pamatují prostřednictvím vyprávění či výkladu ve škole? Jak sdílené narativy a diasporické vědomí podmiňují migraci českých krajanů do země předků?

Text si klade za cíl odkrýt okolnosti reemigrace banátských Čechů do Česka v období po roce 1989 a jejich následné adaptace na pozadí vlivu osobních sociálních vazeb a oficiálních institucí a institutů napomáhajících reemigraci krajanů. Především se ovšem zaměřuje na to, s jakými očekáváními, plány, ale i závazky k rodině zanechané v Rumunsku banátští Češi do země svých předků

1 Rádi bychom poděkovali anonymnímu recenzentovi za jeho kritické, ale velmi konstruktivní připomínky, které článek významně obohatily.

2 Příkladem může být iniciativa prezidenta Miloše Zemana z roku 2014 v otázce přesídlení volyňských Čechů v souvislosti s vypuknutím konfliktu na Ukrajině. O přesídlení několika desítek rodin českého původu se ve veřejném diskurzu hovořilo zásadně rétorikou "návratu domů“ či „repatriace“. Příkladem mohou být titulky tehdejších novinových článků: „Volyňští Češi našli přímluvu na Hradě. Zeman jim chce zajistit návrat domů“ (ČT24.Cz, 11. 9. 2014) či „Chceme domů! Přes 70 rodin z Ukrajiny žádá Zemana o návrat do Čech“ (Lidovky.cz, 2. 10. 2014). 
odcházejí a jaké okolnosti, obzvláště sociální vazby vstupují do jejich migračních a adaptačních strategií. V článku jsou prezentovány výsledky výzkumu, který byl realizován v Rumunsku v roce 2012 a v Česku v letech 2013 a 2015, ${ }^{3}$ za použití kombinace kvalitativních a kvantitativních metod výzkumu, a který se konceptuálně opíral o teze teorie migračních sítí a institucionální teorie (Massey a kol. 1993) a teorie transnacionalismu (Glick Schiller - Basch - Blanc-Szanton 1995; King - Christou 2010).

\section{„Návrat domů“ jako uzavření kruhu života v diaspoře?}

První českou obcí v oblasti Banátu byla Svatá Alžběta, založená již roku 1823, o rok později ji následovala Svatá Helena, ležící nedaleko od ní jižním směrem (Pavlásek 2010). Několik let po založení Svaté Alžběty však došlo k vyschnutí místních studen a obyvatelstvo se z velké části přestěhovalo právě do Svaté Heleny, a tak první česká obec roku 1847 zanikla (Hirt - Jakoubek 2005). Další české vesnice byly založeny v letech 1827-1828, jednalo se o obce Šumice, Gerník, Eibentál, Bígr, Rovensko a Frauvízn. Posledně jmenovanou však čekal stejný osud jako Svatou Alžbětu a v 60. letech 19. století ji opustili poslední obyvatelé (Jech 1996).

Od příchodu prvních českých osadníků do rumunského Banátu ve 20. letech 19. století provází tuto českou enklávu snahy o „návrat“ do země předků (Salzmann 1983). Reemigrace však byla v několika ohledech mimořádně obtížná a často jí byly kladeny administrativní překážky; v důsledku toho k ní docházelo jen sporadicky. Jak poukazuje Jech a kol. (1992), již samotný př́íchod byl spojen s přísnými podmínkami, které až do roku 1832 znemožňovaly imigrantům návrat do českých zemí. Díky postupnému uvolnění pravidel pokračovala imigrace i dále ve 40. a 50. letech 19. století. Avšak již o poznání menší skupiny kolonistů směřovaly nikoliv do hor, ale primárně do níže položených oblastí srbského Banátu.

Po roce 1832 rovněž dochází k sekundární migraci českých krajanů z hornatých oblastí rumunského Banátu do nížin na druhé straně Dunaje (Jech a kol. 1992). Prvně založenou českou obcí v srbské části Banátu byla vesnice Ablian (nebo také Češko Selo). Postupem času se početně největší českou obcí v oblasti stala Krušice, dalšími významnými středisky na srbské straně řeky byly Velké Srediště a Velký Bečkerek. V dalších letech se čeští osadníci rozšířili také do okolních obcí, především do Jasenova, Gáje a Bele Cerkve, která je zároveň největším sídlem v oblasti (Kokaisl a kol. 2009).

Návrat nebyl krajanům umožněn ani po vzniku samostatného Československa v roce 1918, kdy v Rumunsku žili již zástupci čtvrté migrační generace. $\mathrm{V}$ té době mnoho z nich zaslalo kompetentním československým

3 Výzkum byl realizován v rámci bakalářské práce (Kres| 2012), ale zejména diplomové práce (Kresl 2015) jednoho z autorů článku, Zdeňka Kresla; diplomová byla obhájena na katedře sociální geografie a regionálního rozvoje Př́rodovědecké fakulty Univerzity Karlovy v Praze v červnu 2015. 
orgánům písemnou výzvu, ve které se odvolávali na neutěšitelnou hospodářskou situaci v Rumunsku, a vyslovili přání být součástí samostatného státu Čechoslováků. Tato žádost však nebyla vládními institucemi vyslyšena (Vaculík 2009). Vláda dokonce došla k závěru, že reemigrace není v dané době, kdy se země potýkala s krizí, vhodná ani žádoucí (Korostenski - Pána 2011).

Do roku 1989 se vyskytlo pouze jedno období, během kterého byla reemigrace administrativně a finančně podpořena československými institucemi. Nastalo krátce po konci druhé světové války v souvislosti s vládním cílem dosídlit vylidněné oblasti po odsunutém německém obyvatelstvu (Vaculík 2003). Řízený návrat byl zahájen podpisem Dohody o transferu rumunských občanů a bezdomovců mezi československou a rumunskou stranou dne 10. července 1947 (Heroldová 1983). Druhá významná vlna reemigrace banátských Čechů do Česka vyvstala v souvislosti s odstraněním migračních bariér v roce 1989. Reemigrace etnických Čechů z Rumunska nebyla a ani není garantována žádnou mezinárodní smlouvou. Reemigranti si musí cestu zařídit a financovat sami a splnit stejné zákonné podmínky pro získání některého z typů pobytu jako kterýkoliv jiný cizinec (Nešpor 2002), resp. od roku 2007 jako euroobčan. Proto reemigrace banátských Čechů po roce 1989 není skupinová, ale spíše individuální či rodinná, na základě vlastní iniciativy migrantů.

Okolnosti pokusů o návrat vytvořily již během života prvních generací Čechů v Rumunsku z pobytu v cizině (byt do roku 1918 v rámci jednoho státního útvaru) jakýsi nucený exil. K emigraci z oblasti však docházelo, a to nemalou měrou. Po celé období do konce druhé světové války se migrační destinací velmi často stávaly oblasti či státy mimo samotné Československo. $\mathrm{Z}$ důvodu relativní přelidněnosti oblasti českých vesnic v Banátu, která byla zapříčiněna především vysokou porodností, dochází již od druhé poloviny 19. století k druhotné migraci. Část místní české komunity reaguje na pobídku přemístění do Bulharska, kde na počátku 20. století zakládají ryze české vesnice Sesek, Vojvodovo a Belinci (Jakoubek 2010). Největší část českých migrantů ale nachází nový domov v Argentině a Spojených státech amerických (Heroldová 1983).

Jak podotýká Reynolds (2008: 10 in: King - Christou 2010), „návrat“ do země předků (,ancestral return“) se v situaci takovýchto administrativních překážek může pro členy diaspory stát ústředním narativem rodiny i komunity a jakousi zděděnou povinností, nutností a touhou po uzavření cyklu života v diaspoře. Narativ „návratu“ a domova sdílený rodiči přejímají za vlastní i jejich děti, kterým navíc pomáhá porozumět své vlastní identitě. Výrazným narativem, se kterým jsme se během výzkumu mezi rumunskými Čechy setkávali, byl právě obraz Česka jako „domova předků“ či místa, kde se mohou cítit „jako doma“. Další sdílenou a akcentovanou představou bylo vnímání Česka jako „země, kde se lidé mají lépe“ či „země, kde vše funguje“. o Česku je tedy primárně uvažováno jako o „domově“ či místě, které může být „jako doma“, ale zároveň i jako o ekonomicky výhodnější alternativě pro 
život. Právě vidina zlepšení životní úrovně je jedním z hlavních push a pull faktorů vedoucích k odchodu z Rumunska a příchodu do Česka, což potvrdily i výsledky výzkumu.

Idea „návratu“ je udržitelná po tolik generací jen díky pevné a fungující diaspoře. Dle Gottmannova konceptu ikonografie (Gottmann 1952, in: Bruneau 2010) je pro zachování životaschopnosti diaspory zásadní, aby měli její členové možnost setkávat se někde za náboženskými, kulturními či politickými účely a aby měli stabilní místa, kde mohou soustřed'ovat hlavní prvky ikonografie diaspory, např́iklad materiální projevy religiozity, fotografie země původu či různé tradiční předměty. Česká diaspora v Banátu existuje téměř dvě století. A nejedná se pouze o oněch šest více méně etnicky homogenních obcí, ale i o etnické Čechy žijící jako menšinové obyvatelstvo v rumunských městech (Oršava, Nová Moldava), obcích podél Dunaje (Berzáska, Liubcova, Dubova, Zlatice atd.) a rovněž v srbské části Banátu (Češko Selo, Bela Cerkev, Jasenovo, Gáj, Krušice, Velké Srediště, Velký Bečkerek). Důležitou roli v udržení životaschopnosti diaspory sehrávají právě místa (především kostely, hřbitovy, hostince a školy) a komunitní aktivity (oslavy svátků, svatby, pohřby, masopust, posvícení či tradiční pout místních českých katolíků do Čiklavy), ale i celková odlehlost českých obcí od okolí (Pavlásek 2013). V neposlední řadě však i transnacionální vazby a praktiky diaspory, které byly individuální i institucionální povahy.

\section{Transnacionální vazby a rozhodování k migraci}

Český stát (či jeho předešlé formy) na jednu stranu aktivně reemigraci krajanů nepodporoval, na druhou však vždy vyvíjel úsilí udržet si v krajanských komunitách v Rumunsku svůj kulturní vliv. České úřady už od prvních let do oblasti vysílaly pedagogy a duchovní, kteří realizovali veškeré aktivity v mateřštině. Od této praxe si úřady slibovaly hlavně zabránění asimilace (Pavlásek 2011), sekundárně však docházelo k udržování a posilování transnacionálních vazeb krajanů na zemi předků. Ty byly živeny i díky emigraci některých krajanů do Česka a následným návštěvám příbuzných v Rumunsku, či pomocí poštovní korespondence.

Důležitou transnacionální praktikou vždy bylo i zasílání remitencí. Velkým mezníkem v porevoluční (ekonomické) migraci představovaly nábory pracovníků do továrny Mitas, a. s., v pražské Hostivaři v druhé polovině 90 . let 20. století. Budoucí zaměstnanci byli vyhledáváni přímo v českých obcích v Rumunsku, což výrazně posílilo již tak existující reemigrační vlnu. Jak uvádí Hanus (2011), pro mnohé dělníky z řad krajanů to byla výhodná možnost zisku počátečního kapitálu a možnosti se dále v budoucnu v Česku natrvalo usadit. Další prohloubení transnacionálních aktivit představovalo otevření cívkárny Winding přímo v Gerníku, kterou vlastní členové jedné z rodin reemigrantů žijících v českých Kasejovicích. 
Od roku 1989 se spektrum transnacionálních kontaktů stává ještě rozmanitější. Do poloviny 90 . let 20. století nebyl ze strany Česka patrný téměř žádný výraznější zájem o krajanské komunity v zahraničí, situace se však změnila v roce 1994, kdy v Banátu zahájila svou činnost společnost Člověk v tísni, ale zejména v roce 1995, kdy se otázkou podpory a zachování českého kulturního dědictví v zahraničí začaly zabývat i kompetentní české úřady na úrovni parlamentu a vlády. V prvním programovém období v letech 1996-2001 byly krajanské komunity podporovány formou rozvojových projektů. Do roku 2010 byl kladen důraz zejména na opravu a údržbu krajanských objektů a od roku 2011 především na výuku českého jazyka a zachování vědomého českého původu u nejmladší generace (Kázecký 2014). Výuka českého jazyka však má v oblasti dlouhou historii, první čeští učitelé dorazili do českých vesnic Gerník a Svatá Helena již roku 1857, resp. 1863 (Kokaisl a kol. 2009). Vedle aktivit iniciovaných na nejvyšší politické úrovni vznikají i partnerské kontakty mezi českými obcemi v Rumunsku a v Česku, které vedou k vzájemnému propojení, výměně zkušeností, navštěvování představitelů obcí či k výměnným pobytům mládeže.

Paradoxem těchto aktivit je, že zatímco jejich primárním cílem bylo podpořit životaschopnost a rozvoj české diaspory v zahraničí, místo toho mnohdy vedly spíše k iniciaci migrace do Česka. Jak dokládají Massey a kol. (1993), Castles (2004) a mnoho dalších, různé formální i neformální instituce a instituty mohou v migračním rozhodování zastávat stejně důležitou roli jako osobní migrační sítě či pocit relativní deprivace. Instituce mohou migraci jednak zpř́ístupnit širším skupinám osob proaktivním jednáním, například formou různých náborových programů či přesidlovacích iniciativ, ale i blokovat, například zavedením víz či zpř́ísněním podmínek pobytu. Jak se ukázalo, důležitou roli v migračním rozhodování českých krajanů mohla sehrát i činnost institucí, jež s migrací primárně vůbec nesouvisejí, jako jsou kupříkladu společenské akce krajanských spolků či v obcích realizované rozvojové projekty, ale rovněž kontakt s českými státními příslušníky, kteří začali po roce 1989 jako turisté oblast Banátu hojně navštěvovat, s místními se družně setkávat a také u nich nocovat. De Jong a Fawcett (1981) tento stav popisují jako rozvoj kognitivní dostupnosti alternativ. To znamená, že je potenciálním migrantům vůbec umožněno uvažovat o emigraci, tedy o sobě jako o migrantech, ale zejména o Česku jako o alternativě jejich života. Jak autoři dodávají, důležitá je nejenom možnost fyzicky se přestěhovat, nebo zůstat, ale člověk si musí být rovněž vůbec vědom toho, že je možné takový výběr udělat. Častý přímý kontakt s Českem, díky českým učitelům, duchovním, výzkumníkům, turistům, koordinátorům rozvojových projektů, ale také osobním návštěvám atd., umožnil potenciálním migrantům dávat návratovým úmyslům konkrétní podobu. Transnacionální praktiky, kdy lidé z Česka aktivně navazují transnacionální kontakt mezi Českem a Čechy z rumunského Banátu, navíc mohly podpořit představu země předků jako vítající země, jako země, která je „domovem“. 
Představa života „v exilu“, mimo domovinu, byla svým způsobem institucionalizována zavedením tzv. potvrzení o př́íslušnosti k české krajanské komunitě v zahraničí, které na základě žádosti doložené listinnými doklady vystavuje zvláštní zmocněnec pro krajanské záležitosti (Eisenbruk 2009). Potvrzení slouží primárně k úřednímu posvěcení českého původu, avšak s občanstvím nemá nic společného. Nicméně po doložení dalších zákonem stanovených náležitostí (dokladu o zajištění ubytování, dokladu o zajištění finančních prostředků, výpisu z rejstř́íku trestů a vyplněné žádosti o trvalý pobyt) může dle $\S 66$, odstavce 1, písmene b) zákona č. 326/1999 Sb., o pobytu cizinců posloužit k získání povolení k trvalému pobytu. Ambicí potvrzení bylo zejména zmírnit přísné podmínky vstupu a pobytu na území Česka pro české krajany, kteří byli v postavení cizince. Tím jim úřady dávaly najevo, že byt jsou po právní stránce cizinci, česká společnost je vnímá jako svou detašovanou součást.

Jak dokládají výstupy z výzkumu, čeští krajané potvrzení pro účely přesídlení do Česka využívali, především v době před vstupem Rumunska do EU. V našem vzorku je využili nejvíce respondenti, kteří přišli mezi léty 2000 a 2007. V roce 2000 vstoupil v účinnost již zmíněný zákon č. 326/1999 Sb., o pobytu cizinců, který ve srovnání s předchozím obdobím značně zpřísňoval podmínky vstupu a pobytu cizinců na území (Kušniráková - Čižinský 2011). Naopak v roce 2007, kdy se Rumunsko stalo členem EU, došlo ke zrušení řady administrativních překážek pro rumunské občany, kteří na území Česka získali téměř totožná práva a přístup na trh práce, do zdravotního pojištění, sociálního sytému atd. jako občané České republiky. Z 36 dotazovaných, kteří přesídlili v té době do Česka, 18 toto potvrzení využilo (přičemž 7 neodpovědělo), kdežto v období let 1990 až 1999 je využilo 11 z 33 dotázaných (3 lidé neodpověděli).

\section{„Návrat" pohledem čísel}

Přestože až do roku 1989 nebylo přesídlení pro rumunské Čechy příliš snadné, mnohým se podařilo je uskutečnit. Další přicházejí po roce 1989, a dokud to bude populační velikost obcí dovolovat, budou nejspíše přicházet i nadále. Stejně tak lze ale předpokládat, že se budou i navracet, zejména ke stáří, ze sentimentu, za hroby svých předků, za kořeny. Přesné statistiky počtu krajanů z Rumunska či oblasti Banátu, kteří od roku 1989 přesídlili do Česka, však známé nejsou. Přesto je možné určitý hrubý odhad provést na základě dat z rumunského sčítání lidu. Počet obyvatel českého původu v Rumunsku celkově mezi lety 1992 a 2011 klesl o 3323 osob. Zdá se pravděpodobné, že v obdobích mezi lety 1989 a 1992 a od roku 2011 do současnosti, za které nemáme údaje, odešly další stovky lidí.

Při pohledu na údaje úbytku obyvatel českého původu z let 1992, 2002 a 2011 (tab. 1), resp. statistiky počtu obyvatel v českých obcích v rumunském Banátu z týchž let (tab. 2) tedy můžeme odhadovat, že potenciálně mohlo do Česka přesídlit až 3500 lidí. Jedná se ovšem o hodnotu krajní, která nezohledňuje úbytek 
úmrtím. V roce 2012 (námi dotazovaní) banátští Češi v obcích Svatá Helena a Rovensko vyjadřovali pocitovaný počet odchozích slovy, že „naprostá většina Čechů odešla do Česka, ten zbytek v rámci Rumunska“ (poznámky z terénu). Pokud tedy zohledníme i přirozený úbytek, dá se předpokládat, že od roku 1989 do roku 2011 do Česka přesídlilo okolo 3000 rumunských Čechů, z nich naprostá většina (cca 4/5) z oblasti Banátu a ostatní ze zbytku Rumunska.

Tab. 1 Počet obyvatel českého původu v Rumunsku dle cenzu v letech 1992, 2002, 2011

\begin{tabular}{|c|c|c|c|c|}
\hline obec & $1992^{*}$ & $2002^{* *}$ & $2011^{* \star *}$ & rozdíl 1992-2011 \\
\hline $\begin{array}{l}\text { obyvatelé českého původu } \\
\text { v Rumunsku celkem }\end{array}$ & 5800 & 3938 & 2477 & 3323 \\
\hline $\begin{array}{l}\text { obyvatelé českého původu ve dvou } \\
\text { hlavních župách Banátu }\end{array}$ & N/A & N/A & 2022 & N/A \\
\hline $\begin{array}{l}\text { obyvatelé českého původu mimo } \\
\text { dotčené dvě banátské župy }\end{array}$ & N/A & N/A & 455 & N/A \\
\hline $\begin{array}{l}\text { obyvatelé českého původu v šesti } \\
\text { českých obcích v Banátu }\end{array}$ & 2966 & 1918 & 1319 & 1647 \\
\hline
\end{tabular}

Zdroj

* Krajané - Po stopách Čechů ve východní Evropě. Praha, Za hranice - Společnost pro rozvojovou spolupráci při Provozně ekonomické fakultě ČZU v Praze, 2009

** Rumunské sčítání lidu 2002 - Recensământul Populației și al Locuințelor 2002, dostupné z: http://www.kia.hu/konyvtar/erdely/erd2002/etnii2002.zip [2015-08-29]

*** Rumunské sčítání lidu 2011 - Recensământul Populației și al Locuințelor 2011, dostupné z: http://www.recensamantromania.ro/wp-content/uploads/2014/01/ rpl_2011_populatia-pe-categorii-de-localitati.xls [2015-08-29]

Tab. 2 Počet obyvatel v českých obcích v Banátu dle cenzu v letech 1992, 2002, 2011

\begin{tabular}{|c|c|c|c|c|}
\hline Obec & $1992^{*}$ & $2002^{* *}$ & $2011^{* * *}$ & rozdíl 1992-2011 \\
\hline Bígr & 360 & 257 & 216 & -144 \\
\hline Eibentál & 375 & 308 & 249 & -126 \\
\hline Gerník & 991 & 524 & 317 & -674 \\
\hline Rovensko & 235 & 165 & 88 & -147 \\
\hline Svatá Helena & 800 & 519 & 360 & -440 \\
\hline Šumice & 205 & 145 & 89 & -116 \\
\hline Celkem & 2966 & 1918 & 1319 & -1647 \\
\hline
\end{tabular}

Zdroj viz tab. 1 


\section{Metodologie výzkumu}

Přesídlení rumunských Čechů do Česka představuje unikátní zkušenost „návratu“ do země, o které se učili jako o své vlasti, ale většinou ji nikdy předtím nenavštívili. Jistě to bylo spojeno s mnoha očekáváními a patriotismem, ale i s celou řadou překvapení. Abychom okolnosti přesídlení banátských krajanů mohli prozkoumat z co nejširší perspektivy a zohlednit makro i mikro pohled, přistoupili jsme k provedení výzkumu ve třech fázích a za použití kombinace kvalitativních i kvantitativních metod. Stěžejní fázi představovalo dotazníkové šetření realizované v březnu a dubnu 2015. Sestavení dotazníku předcházel monitoring v obcích Svatá Helena a Rovensko v rumunském Banátu v dubnu 2012 a zúčastněné pozorování u krajanů přesídlivších do Česka, realizované v letech 2013 a 2015. Cílem předsunutí kvalitativních metod (zúčastněného pozorování a rozhovorů) před samotný sběr dat pomocí polostrukturovaného dotazníku bylo získat podkladový materiál pro jeho sestavní. A tak, přestože klíčovým nástrojem výzkumu bylo dotazníkové šetření, část sběru dat cestou kvalitativních metod byla časově několikanásobně rozsáhlejší (několik měsíců v průběhu výzkumu v letech 2012-2015) než samotná distribuce a sběr dotazníků (2 měsíce).

Během monitoringu v Banátu bylo provedeno několik rozhovorů na téma reemigrace do Česka a významu remitencí jakožto jedné z transnacionálních praktik rumunských Čechů. Klíčovým informantem byl František Roch, ředitel svatohelenské základní školy. Dalšími svatohelenskými informátory, kteří nám laskavě poskytli rozhovor, byli Josef Baštík a Anna Táborská, v Rovensku Karolína Pražáková.

Formou využití částečného insidera, kdy jeden z autorů - Zdeněk Kresl - absolvoval od ledna do dubna roku 2013 stáž na Pracovišti MZV ČR pro krajanské záležitosti, probíhal sběr podkladových informací, na jejichž základě byl sestaven finální dotazník. Jako stážista se zúčastnil pravidelných porad, které se týkaly nastávajícího setkání generálních konzulů, absolvoval několik návštěv pracovníků Ministerstva vnitra České republiky ohledně odhalení falzifikátů potvrzení o českém původu, schůzek s koordinátorem organizace Člověk v tísni pro oblast Banátu Ivo Dokoupilem, setkání s pracovníky Domu zahraniční spolupráce a řadu neformálních setkání s českými krajany žijícími dlouhodobě v zahraničí. Během stáže proběhlo i několik rozhovorů s tehdejším zvláštním zmocněncem pro krajanské záležitosti Stanislavem Kázeckým. Informace a poznatky z prvních dvou fází výzkumu byly zaznamenávány ve výzkumnickém deníku formou nedatovaných poznámek.

Následný dotazník, který byl sestaven na základě získaných informací z předchozích šetření, obsahoval 58 převážně uzavřených otázek, rozdělených do šesti tematických okruhů: 1) odchod z Rumunska a příchod do Česka; 2) role kontaktů a sociálních sítí; 3) život v Česku a kontakt s okolním prostředím a společností; 4) život v Česku a ekonomické aktivity; 5) remitence 
a další transnacionální praktiky; 6) osobní identifikační údaje. Sběr dotazníků probíhal v březnu a dubnu roku 2015. Dotazník byl vytvořen v českém jazyce a šířen v elektronické podobě metodou sněhové koule prostřednictvím facebookových stránek a skupin Rumunsko - Češi a Slováci v Rumunsku, Český Banát, Rodáci z Českého Banátu, banat.cz, Banát - dovolená u krajanů, Festival Banát, Restaurace Český Banát, Gerník, Svata Helena, Rumunsko, Cesi zijici $v$ Rumunsku / pochazejici z Rumunska-Cehi din Romania, Češi a Slováci $v$ zahraničí a krajane.cz. S jeho šířením pomáhali i bývalí majitelé restaurace Český Banát manželé Emílie a Jiří Janečkovi s dcerou Lucií Janečkovou, kteří oslovovali své přátele e-mailem a prostřednictvím facebooku s prosbou o vyplnění dotazníku. Výhradně elektronická cesta získávání respondentů samozřejmě omezuje rozsah oslovených pouze na ty, kteří aktivně používají internet, zejména sociální sít facebook. Autoři jsou si toho vědomi, avšak vzhledem k tomu, že výzkum se zaměřoval na migranty, kteří přicestovali až po roce 1989, a navíc že stěžejní formou transnacionálních praktik migrantů je komunikace s př́buznými pomocí internetu, existuje i vysoká pravděpodobnost, že jsou uživateli sociálních sítí. Právě díky potřebě této komunikace s příbuznými v Česku je téměř každá česká domácnost v Rumunsku vybavena počítačem a rovněž starší generace umí - mnohdy pouze - používat Skype či e-mail. Přesto je důležité zdůraznit, že sebraný soubor ( $\mathrm{n}=79)$ není v žádném ohledu reprezentativním vzorkem, a tak musí být na výstupy z výzkumu také nahlíženo. Avšak vzhledem k poměrně malé a specifické skupině možných respondentů považujeme získaný počet dotazníků za úctyhodný.

\section{Respondentky a respondenti dotazníkového šetření}

Celkem bylo sebráno 81 dotazníků, dva byly vyřazeny jako duplicitní. Z celkového počtu 79 respondentů zahrnutých do analýzy bylo 68,3 \% žen a 31,7 \% mužů. Všichni respondenti se v době výzkumu nacházeli v produktivním věku 15-65 let. Většina byla mladší 45 let (15-25 let - $20 \%$; 26-35 let - 41,7 \%; 36-45 let - $20 \%$ ), 11 osob bylo starších a 11 lidí otázku aktuálního věku nevyplnilo.

Naprostá většina dotazovaných přišla do Česka ve věku do 23 let včetně: 1) do 14 let věku 27,3\%; 2) ve věkovém rozmezí 15-18 let 27,3 \%; 3) ve věku 19-23 let 30,3 \%. Ostatní dotazovaní byli v době příchodu starší 24 let, ale až na jednu osobu mladší 28 let. Tuto praxi, kdy většina českých krajanů z Banátu přichází do Česka krátce po ukončení studií, potvrdily i zkušenosti Ivo Dokoupila, Františka Rocha a manželů Janečkových. Ti jsou názoru, že české obce v Banátu nenabízejí mladým lidem mnoho perspektiv, jelikož „málokdo chce v dnešní době pracovat v zemědělství“ (poznámky z terénu) a jiné alternativy vesnice téměř neposkytují. Z toho důvodu odcházejí mladí lidé i z okolních nečeských obcí zejména do měst v rámci Rumunska, Češi především do Česka.

$\mathrm{Na}$ otázku týkající se vzdělání odpovědělo pouze 60 dotazovaných, z nichž 18 mělo v době výzkumu dokončené pouze základní vzdělání (2 osoby stále 
studují), 15 osob středoškolské bez maturity, 21 s maturitou a šest osob vzdělání vysokoškolské ( 5 z nich vystudovalo v Česku). Ve věkové kategorii příchodu do Česka 17-23 let si žádná osoba po příchodu vzdělání již nedoplnila, naopak všichni ihned nastoupili do pracovního procesu.

V našem vzorku též převažovala migrace lidí bez závazků, tedy svobodných a bezdětných (39 dotázaných), nad osobami sezdanými a s dětmi ( 8 bez dětí, resp. 13 s dětmi). Z výsledků dotazníkového šetření vyplývá, že v 90. letech převažovala migrace rodinná nad migrací individuální, jejíž význam narůstá od přelomu tisíciletí. V 90. letech, zejména v jejich první polovině, přesídlili do Česka až na jednu osobu všichni sezdaní respondenti a dalších 16 osob mladších 16 let jako děti následující rodiče. Toto zjištění je však v rozporu s tvrzením Secké (1996), podle níž v první polovině 90. let přicházeli zejména jednotlivci, převážně mladí lidé krátce po ukončení školy, kteří se vydávali za příbuznými do Česka s vidinou velkého výdělku.

Jednotlivé podíly respondentů žijících v současné době v Česku podle obce původu v zásadě kopírují dnešní populační velikost těchto sídel. Pouze u respondentů z Rovenska byl zaznamenán vyšší, naopak z Eibentálu nižší počet. To může souviset i se skutečností, že byt Rovensko bylo vždy populačně menší, vylidňování je postihlo výrazněji než Eibentál, a tedy v Česku může být potenciálně více Čechů z Rovenska než z Eibentálu. Rozdíl by mohl

Obr. 1 Obec původu respondentů dotazníkového šetření ( $n=79)$

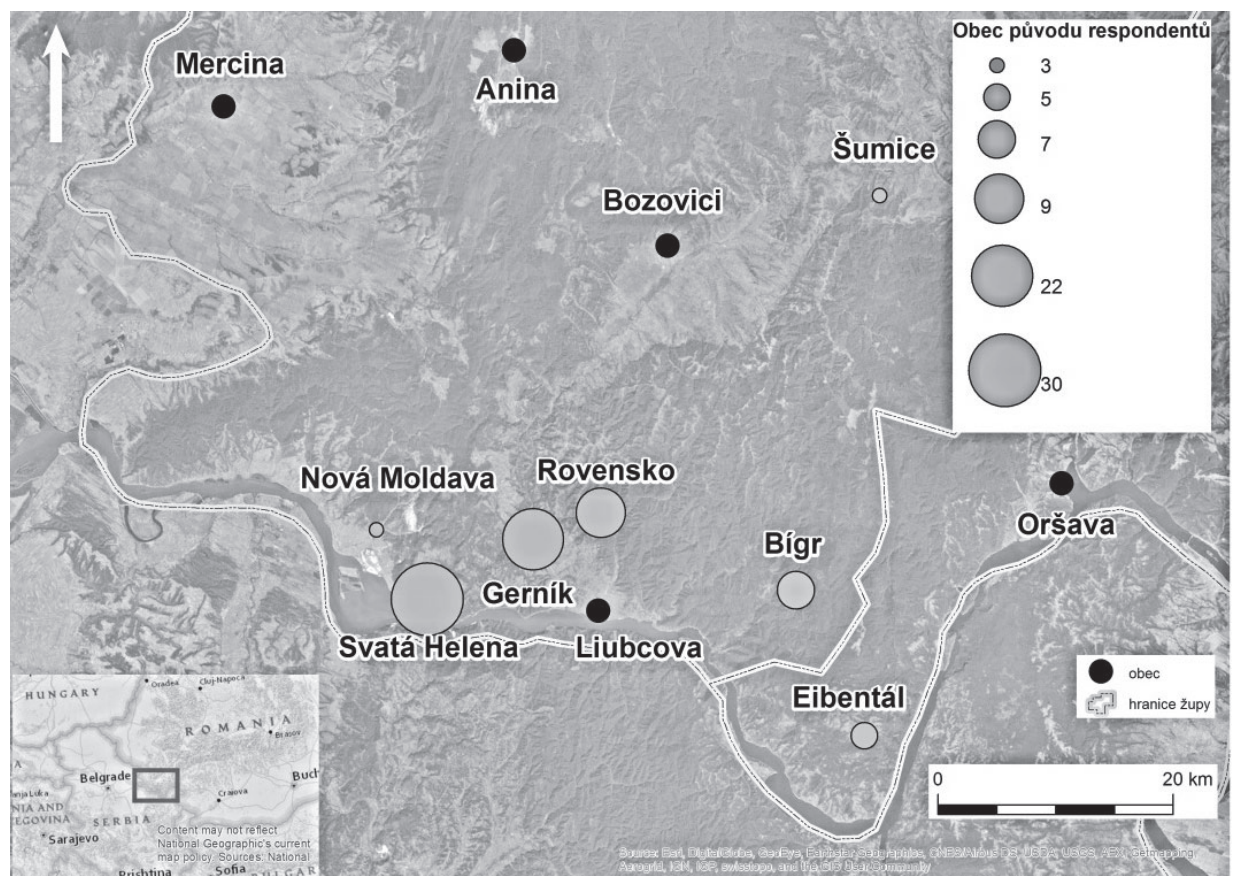

Zdroj Global Administrative Areas; Mapping Hacks; Map Library 
souviset i s metodou sběru dat pomocí sněhové koule, která využívá osobní sociální vazby a kontakty oslovených respondentů a bez klíčového kontaktu nemusí informace o výzkumu projít z jedné skupiny potenciálních respondentů do druhé. To otevírá i otázku, do jaké míry jsou rumunští Češi pocházející z jednotlivých obcí Banátu i mimo něj provázáni. Vedle dotčených šesti banátských obcí se ve vzorku vyskytli i tři respondenti původem z Nové Moldavy (obr. 1).

\section{Vliv migračních sítí a transnacionálních vazeb na přesídlení do Česka}

Migrační sítě, tedy mezilidské vazby spojující prostřednictvím př́íbuzenských pout, přátelství či vědomí společného původu migranty, bývalé migranty a nemigrující v rodné zemi a cílové destinaci (Massey 1988), významně ovlivňují migrační rozhodování a osobní migrační a adaptační trajektorie a strategie. Představují určitý sociální komfort, usnadňující migraci a následné usazení nově příchozích, a nezanedbatelně asistují při hledání práce či bydlení. Význam a vliv migračních sítí roste s mírou vnitřní provázanosti dané skupiny (ve zdrojové i cílové zemi). Tato provázanost je v případě banátských/ rumunských Čechů velmi silná, což je dáno i velikostí komunity a blízkostí (osobní i geografickou) původních míst bydliště v Rumunsku, ale jak dokazují výsledky výzkumu, i v Česku. Hanus (2009) dokonce tvrdí, že až do dnešních dní lze v Česku rozlišit jednotlivé krajanské komunity/sítě, které odrážejí konkrétní obec původu v Rumunsku (například bývalí rovenští obyvatelé nadále udržují těsné vztahy s rovenskými a podobně). Jak dodává Hanus (2009), nejedná se tedy o jakýsi homogenní celek, jak by mohl laik předpokládat.

Migrace rumunských Čechů do Česka je zásadní měrou ovlivněna právě existencí dobře etablované migrační sítě, jejíž základy položili zejména reemigranti z poválečného období, kteří i po přesídlení do Československa stále udržovali kontakt s příbuznými v Rumunsku. ${ }^{4}$ Až na pět respondentů, kteří v době prríchodu do Česka v zemi nikoho neznali, přicházela drtivá většina osob za asistence již dříve odešlých, nejčastěji členů širšího příbuzenstva (graf 1). Většina dotázaných (57) též uvedla, že hlavním zdrojem informací o přesídlení a životě v Česku byli právě známí a příbuzní v Česku. Na oficiálních místech se naopak o možnostech a podmínkách přestěhování informoval pouze jediný respondent. 
Graf 1 Přítomnost příbuzných/známých v Česku před příchodem (n=77)

člen širšího príbuzenstva

kamarádi/známí

blízcí př́buzní vyjma partnerů/manželů (rodiče, prarodiče, sourozenci,potomci)

manžel/manželka; partner/partnerka

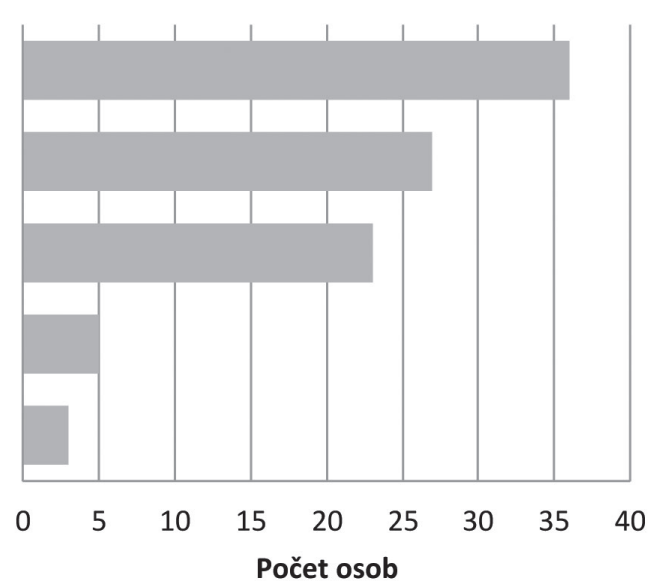

Poznámka Jednalo se o uzavřenou otázku s možností více odpovědí.

Obr. 2 Obec a kraj současného bydliště respondentů v Česku $(n=64)$

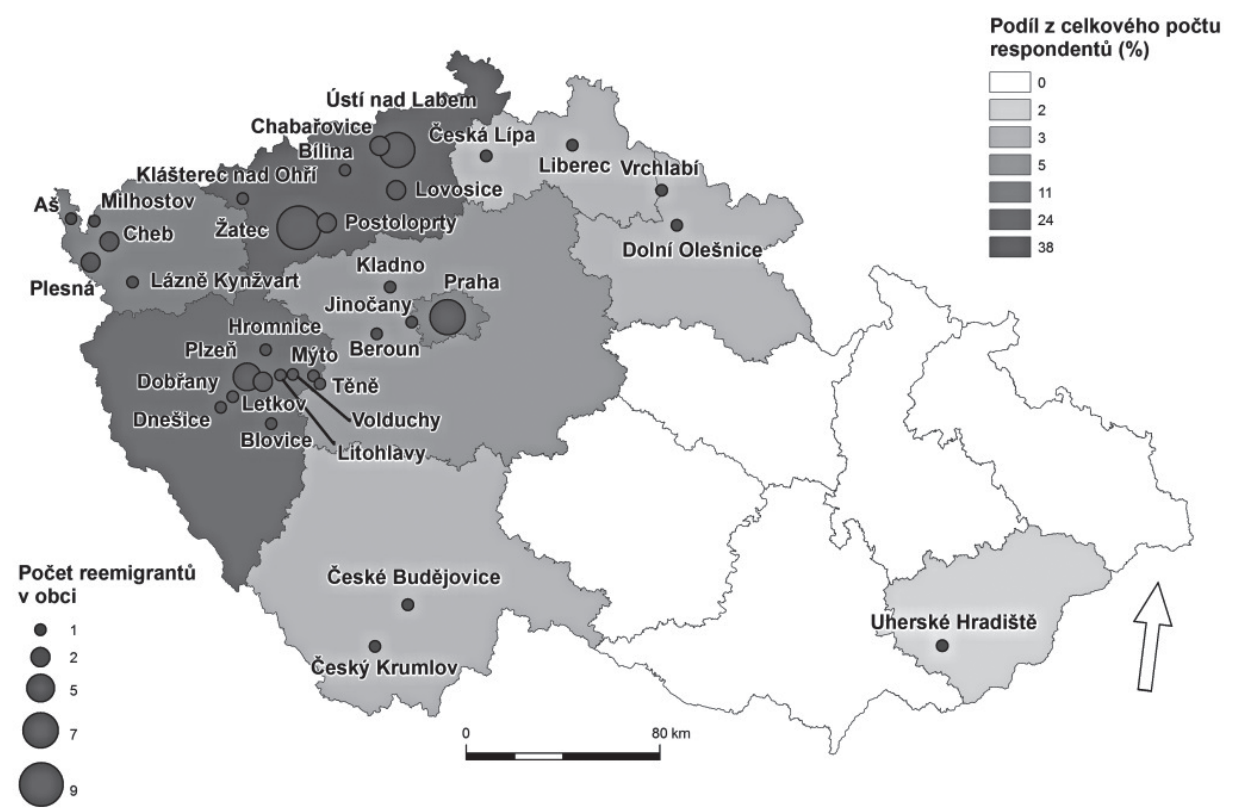

Poznámky Vlastní zpracování

Zdroje data získaná na základě výzkumu; Arc data ČR 500, dostupné v rámci programu ArcGis či na adrese: http://www.arcdata.cz/produktya-sluzby/geograficka-data/arccr-500/, cit. [2015-04-15] 
Funkčnost a sílu sociálních vazeb mezi rumunskými Čechy v Česku a v Rumunsku dokládá také skutečnost, že většina nově příchozích (51 dotázaných) se v první fázi svého pobytu usadila ve stejné obci, kde již někteří jejich příbuzní či známí žili, či nedaleko ní (obr. 2). To znamená zejména v západních a severních Čechách, tedy v místech, kam směřovali rumunští Češi z poválečné řízené reemigrace. Praxi využívání sociálních sítí zejména během prvních let přesídlení potvrzuje ve svém výzkumu i Secká (1996).

Migrační sítě a osobní vazby sehrály podstatnou roli i v oblasti ekonomických aktivit, zejména volby ekonomické strategie (zaměstnanec či OSVČ) a výběru zaměstnání. Necelá polovina dotázaných (33osob) získala své první pracovní místo po příchodu do Česka za pomoci již usazených příbuzných či známých, 25 si ji vyhledalo samo, 6 využilo služeb úřadu práce, 2 pracovní agentury a jedna osoba si našla práci na internetu. Zbylí stále studují, či neodpověděli. Asistence př́ibuzných a známých se pozitivně promítla i do doby hledání práce. Ti, kterým pomáhali již přesídlení krajané, nalezli práci rychleji než ti, kteří si ji hledali sami. Téměř polovina respondentů nastoupila do zaměstnání ihned či během několika dnů po přestěhování, 11 nalezlo zaměstnání během několika týdnů a 7 v průběhu několika měsíců. Pouhých 8 jedinců nalezlo práci až po roce, zbývajících 10 ještě nezačalo pracovat, z nich 7 studuje. Ostatní neodpověděli.

\section{Ekonomické push a pull faktory}

Téměř 90 \% respondentů dotazníkové části výzkumu uvedlo, že před odjezdem očekávalo „výrazné“ či alespoň „částečné“ zlepšení ekonomického statusu. Nicméně, jak vypovídají výstupy šetření, představy migrantů bývají často před odchodem do Česka poměrně nerealistické a migranti mnohdy ve svých úvahách nezvažují všechny reálné náklady, které je čekají. Podle vyjádření manželů Janečkových má podstatná část krajanů zejména v prvních letech problémy s financemi, zejména s pravidelnými měsíčními splátkami (nájmem, zálohami za vodu, plyn apod.), na které nebyli v Rumunsku vzhledem k dostupnosti zdrojů (vlastní dům, voda) zvyklí, nebo přinejmenším ne v takových částkách, v jakých se v Česku obvykle pohybují. Navíc podle názoru Františka Rocha (výše zmíněného učitele ze svatohelenské základní školy) migranti, kteří přicházejí do Rumunska navštívit své příbuzné, se o počátečních obtížích příliš nezmiňují a nepř́ijemné informace si nechávají spíše pro sebe. F. Roch si tuto strategii vysvětloval pocitem studu, který migrantům brání o nepř́ijemných věcech mluvit a riskovat před ostatními ztrátu tváře, ocitnout se v pozici „toho, co neuspěl“.

Další překážku pro (rychlé) naplnění snu ekonomického zlepšení představuje potíž s nalezením zaměstnání. Zejména díky pomoci již přesídlivších krajanů nacházeli sice nově prríchozí práci poměrně rychle, často se však jednalo 
o činnost mimo obor nebo o málo placené pozice. Důvodem byla zejména nízká úroveň dosaženého vzdělání (základní u 18 respondentů) nebo absence dostatečných zkušeností a dovedností potřebných k tomu, aby na trhu práce uspěli v rozsahu potřebném pro uspokojivé pokrytí nákladů na život. V prvních letech ovšem na méně kvalifikovaných pozicích či ve zcela jiném oboru pracovali i ti, kteří kvalifikaci a zkušenosti měli. Na druhou stranu celkově 53 z 61 respondentů, kteří odpověděli na danou otázku, shodně uvádělo, že se jejich životní úroveň postupem let „výrazně“ $(n=27)$ či alespoň „částečně“ $(n=26)$ zlepšila. Právě úspěšné příběhy reemigrantů představují důležitý pull faktor, podmiňující pokračující migraci z Banátu do Česka.

Jak zjistil Lukáš Hanus (2011), představuje další významný bod mozaiky push a pull faktorů generační konflikt mezi rodiči a prarodiči, který se začal objevovat již od 60. let 20. století, a to v souvislosti s otevřením dolů v oblasti a opouštěním tradičního životního stylu spojeného s prací v zemědělství. Tento konflikt vyvrcholil v 90. letech, kdy došlo k opětovnému uzavření dolů, v jehož důsledku mladší generace musela hledat práci jinde, nebo se navrátit k těžké dřině na poli. Zejména pro mladé nebyla tato druhá varianta příliš lákavá, ale žádné další možnosti se v oblasti téměř nevyskytovaly. Po otevření hranic v 90. letech 20. století proto velká část místních viděla naději v uplatnění právě v Česku. Hanus (2011) též dodává, že vedle touhy skoncovat s osudem těžké práce na poli sehrála $v$ této době v rozhodovacím procesu snaha mladší generace vymanit se z vlivu svých rodičů, majících tradičně tendenci ovlivňovat život svých potomků, někteří dokonce i po jejich přestěhování do Česka. Tyto snahy se však povětšině míjejí účinkem. Odchod mladé generace navíc přinesl zcela novou situaci: ti banátští Češi, kteří v Rumunsku zůstali, nemají své rady, znalosti a movité i nemovité věci komu předávat; navíc jsou nuceni přihlížet trvajícímu vylidňování obcí a v důsledku toho u nich roste pocit nespokojenosti.

\section{Transnacionální praktiky a život v Česku}

Z celkového počtu dotázaných ( $\mathrm{n}=79)$ mělo v době výzkumu 32 osob pouze české státní občanství, 18 jen rumunské a 10 české i rumunské - 19 osob neodpovědělo. Bez výjimky všichni respondenti, kteří měli pouze českou státní př́íslušnost, a osm z těch, kteří měli dvojí občanství, přišli do Česka před vstupem Rumunska do EU v roce 2007. Počet držitelů českého státního občanství je pozoruhodný zejména v kontextu pravidel nabývání a pozbývání českého státního občanství před datem 1.1.2014, kdy vstoupil v účinnost nový zákon o státním občanství; ten již povoluje vícečetná občanství bez výjimek. Původní právní úprava, na základě které získávali státní občanství i naši respondenti, totiž až na výjimky dvojí občanství nepovolovala. Žadatel se tedy musel před udělením českého občanství nejprve vyvázat ze svého občanství původního. Možnost udržet si také ono původní měli pouze ti, kteří na území Česka 
v době žádosti pobývali alespoň 20 let. Skutečnost, že 32 z 60 dotázaných (kteří odpověděli) bylo ochotno se vzdát rumunského občanství ve prospěch českého, svědčí bud' o silné vazbě k Česku a vnitřním ztotožnění se s českou společností, nebo o čistě utilitární snaze získat skrze občanství jistotu svého pobytu a odstranění administrativních bariér v každodenním životě, anebo o kombinaci obojího. Jak z dat šetření vyplývá, nejpravděpodobnější je varianta třetí. $Z$ celkem 18 respondentů, kteří mají pouze rumunské občanství, dvě osoby uvedly, že již o české státní občanství požádaly, a 9 to plánuje, a to i přesto, že jako občané EU mají v Česku - až na brannou povinnost a aktivní a pasivní volební právo na krajské a parlamentní úrovni - práva rovná českým státním občanům. Pouze 4 respondenti uvedli, že nevidí v nabytí českého občanství žádný přínos, jeden respondent o občanství žádat nebude kvůli složitému byrokratickému procesu a jeden z toho důvodu, že uvažuje o svém návratu do Rumunska. Zbývající respondenti se k otázce nevyjádřili.

Občanství může pro člověka představovat administrativní posvěcení vnitř̆ního vnímání své vlastní pozice ve společnosti. Na české krajany se mnohdy nahlíží jako na členy českého národa, kteří pouze žijí daleko od své vlasti. Otázka však je, jak svou pozici v české společnosti a vztah k oběma zemím prožívají oni sami. Návrat několikáté generace krajanů do země svých předků - neboli „,ancestral return“ “či „,counter-diasporic return“ - se v mnohém liší od návratové migrace první generace migrantů. „Kontradiasporičtí“ migranti (tedy x-tá generace potomků původních emigrantů), kteří se vracejí do země předků, si s sebou oproti jiným imigrantům přinášejí pocit přináležitosti ke společnosti přijímajícího státu, mnohdy i jazykovou vybavenost, ale i jakousi rámcovou znalost zásadních historických momentů formování kolektivní identity, která je součástí kolektivní paměti přijímající společnosti. Na druhou stranu jsou také nositeli zvyků, vzorců chování a hodnotového žebřičku země, kde jejich diaspora po generace žila, kde se narodili a kde byli vychováni. V materiálním projevu života rumunských Čechů můžeme vliv rumunského prostředí nalézt zejména v interiéru domácností či v gastronomii, hodnotový projev se odráží ve vyšší míře religiozity a v kladení důrazu na rodinu a rodinné vztahy. Jak uváděli dotazovaní, po příchodu byli zpočátku překvapeni, jak odlišná česká společnost je. Zejména byli zaskočeni jistou citovou chladností, závistivostí a bezbožností. Byli však překvapeni i tím, jak je vnímala česká společnost, respektive tím, jak oni interpretovali přístup domácí populace ke svým osobám. Česká majorita na ně podle nich nahlížela jako na cizince či „ne stoprocentní Čechy“ (poznámky z terénu). To mohlo být dáno jednak absencí občanství, ale například i odlišnostmi v jejich češtině.

Jak poznamenává Kotrbatá (2010), podobnou zkušenost měli i čeští krajané, kteří přesídlili po válce do Československa v rámci řízeného návratu. Uvádí, že většina těchto krajanů byla umistovaná zejména do západních a severních Čech, kde měli zajištěné ubytování a práci, ale od starousedlíků se dočkali chladného přijetí. Zatímco v Rumunsku byli vnímáni jako Češi, 
v Československu na ně bylo velmi často nahlíženo jako na Rumuny a byly jim přisuzovány různé negativní projevy, zejména konzumace alkoholu, negramotnost či nelegální obchod. Negativní reakce starousedlíků na „navrátivší se“ krajany (několikáté generace) jsou popsány také z jiných zemí, například u Řeků přicházejících z USA či u japonských krajanů, tzv. Nikkeijin „vracejících se“ z Brazílie (King - Christou 2010).

Z pohledu přesídlivších krajanů vedlo chladné či kritické přijetí okolím k dekonstrukci vlastní identity. Respondenti uváděli, že v kontextu přesídlení do Česka začali sami o sobě hovořit jako o „rumunských Češích“. O Češích, kteř́ jsou od těch „českých Čechů“v určitých vlastnostech, dovednostech a hodnotách odlišní (poznámky z terénu). Osobní a veřejné přiznání k rumunskosti přišlo až se zkušeností s životem v Česku. King a Christou (2010) tento jev označují jako reaktivní identitu, která se formuje na základě proměny pozice jedince ve společnosti. Podle autorů toto přihlášení se k diasporickému původu slouží jako jakýsi ochranný štít před kritikou a veřejnými soudy. Jako „rumunský Čech“ má totiž navrátilec větší toleranční prostor, než kdyby o sobě hovořil jen jako o „Čechovi“. Př́́kladem může být úroveň češtiny, slovní zásoba a přízvuk. Čeština krajanů, byt je plynulá a krajané všemu rozumějí bez větších obtíží, může na rodilého mluvčího působit zastarale či chybně. Jako „Čech“ se tak mohl krajan stát terčem kritiky a posměchu za nesprávné skloňování či používání archaických výrazů. V krajním případě mohl být označen za hloupého. Přihlášení se $\mathrm{k}$ rumunskému původu potvrdily rovněž výsledky dotazníkového šetření. Z celkových 61 respondentů, kteří se k této otázce vyjádřili, 16 osob uvedlo, že se považuje za Čecha. Oproti tomu 44 osob se považuje za „rumunského Čecha“ či „Čecha původem z Rumunska“. Jedna osoba uvedla, že je to složité. Toto kolektivní vědomí, tato identita „rumunského Čecha“ vznikla až jako reakce na nepochopení nové kultury či společnosti, a to na obou stranách. Hanus (2011) v kontextu dekonstrukce identity uvádí, že postupem času krajané absorbují některé vzorce chování či kultury, velmi snadno např́iklad přijímají výdobytky konzumní společnosti. Největší odlišností od majority je podle něj vysoká religiozita této komunity, s velkým důrazem na rodinu a tradiční model koloběhu života. Tato identita „rumunského Čecha“ pak slouží jako obrana a identifikace sebe sama - „kdo jsem“, „kam patřím“ (Hanus 2011).

Vědomí rumunského původu je posilováno i velmi silnou vazbou na Rumunsko, kde má každý z respondentů nějakého příbuzného, kterého bud pravidelně navštěvuje, nebo s ním je v opakovaném kontaktu. Pouze 7 respondentů z celkových 61 uvedlo, že do Rumunska nejezdí téměř vůbec a 2 maximálně jednou za 5 let. Většina se však snaží příbuzné v Rumunsku osobně navštěvovat co nejčastěji. Minimálně jednou za 2-4 roky do Rumunska jezdí 27 respondentů, 16 se vrací každoročně a 9 dokonce několikrát do roka. Na druhou stranu se však neukázalo, že by kontakt s příbuznými byl udržován na ekonomické bázi. Oproti očekáváním zasílalo v našem vzorku peníze svým 
příbuzným do Rumunska minimum dotázaných. Z 53 odpovídajících respondentů remitovalo pouze 12, z toho 6 zrrídkakdy, 5 nepravidelně a 1 pravidelně několikrát do roka.

Podle výsledků dotazníkového šetření finance neplynuly ani opačným směrem, což je v rozporu jak s výpověd'mi Františka Rocha a Ivo Dokoupila, tak i se zjištěními Lukáše Hanuse, který zejména u Čechů z obce Gerník identifikoval zasílání remitencí (finančních darů) od rodičů žijících v Rumunsku svým potomkům do Česka. Hanus (2011) tento obrácený remitenční směr vysvětluje jako „stavební kameny mezigenerační solidarity“ a dodává, že zasíláním finanční podpory svým dětem se rodiče snaží udržet si svůj sociální status rodičů jako autority. Podle zkušeností F. Rocha a I. Dokoupila (zaměstnance Člověka v tísni) je zejména v počátečních letech po přesídlení běžné, že rodiče a příbuzní reemigrantů v Rumunsku, přivydělávající si také cestovním ruchem, zasílají peníze svým potomkům a dalším příbuzným do Česka: po přesídlení mají někteří krajané problémy s finančním hospodařením pravidelnými měsíčními výdaji na bydlení a měsíčními splátkami na půjčky, které si v začátcích bral téměř každý $\mathrm{z}$ nich. V Rumunsku nebyli na pravidelné splátky (kromě elektřiny) zvyklí, voda byla zdarma, plyn měli jenom někteří a jen v plynových bombách a potravinově byli částečně soběstační (poznámky z terénu). Tuto praxi pravidelné finanční podpory od příbuzných v Rumunsku přesídleným krajanům do Česka (či naopak) však výsledky dotazníkového šetření nepotvrdily. To může být dáno změnou praxe v průběhu času (Hanusův výzkum byl realizován o několik let dříve, v době ekonomické recese, než výzkum v předloženém textu), výběrem respondentů nebo také tendencí př́jem remitencí z osobních důvodů při výzkumu nepřiznat, i kdyby k nim docházelo.

Kde jsou rumunští Češi doma? Na přímou otázku 38 z nich odpovědělo, že se v současné době už cítí být víc doma v Česku, 21 vnímá jako svůj domov Česko i Rumunsko. Jeden respondent uvedl, že „domov“ je v Rumunsku, ostatní neodpověděli. Většina $z$ nich však shodně odpovídala, že se jim stýská po rumunské krajině a životu spojeném s přírodou. Možná právě stesk po životě ve venkovském prostředí nebo naopak nezvyk na život ve velkých městech ovlivňuje trajektorie rumunských Čechů během jejich života v Česku. Zatímco většina dotázaných po příchodu žila v Praze, v průběhu orientace v českém prostředí se stěhují do menších měst či vesnic (graf 2). Podle F. Rocha, I. Dokoupila či manželů Janečkových velká část mladých hledá ve městě úspěch a rychle získané finance. K lépe ohodnocenému zaměstnání však nemají velmi často požadované vzdělání či kvalifikaci. Po jistém vystřízlivění tedy část z nich z větších sídel odchází (poznámky z terénu). Směr migrace z větších sídel do menších zřejmě souvisí s prvotním neúspěchem či zklamáním z městského prostředí, ale i snahou přiblížit se k poklidnějšímu životnímu stylu jako v Rumunsku. 
Graf 2 Populační velikost obce prvního a současného bydliště $(n=65)$

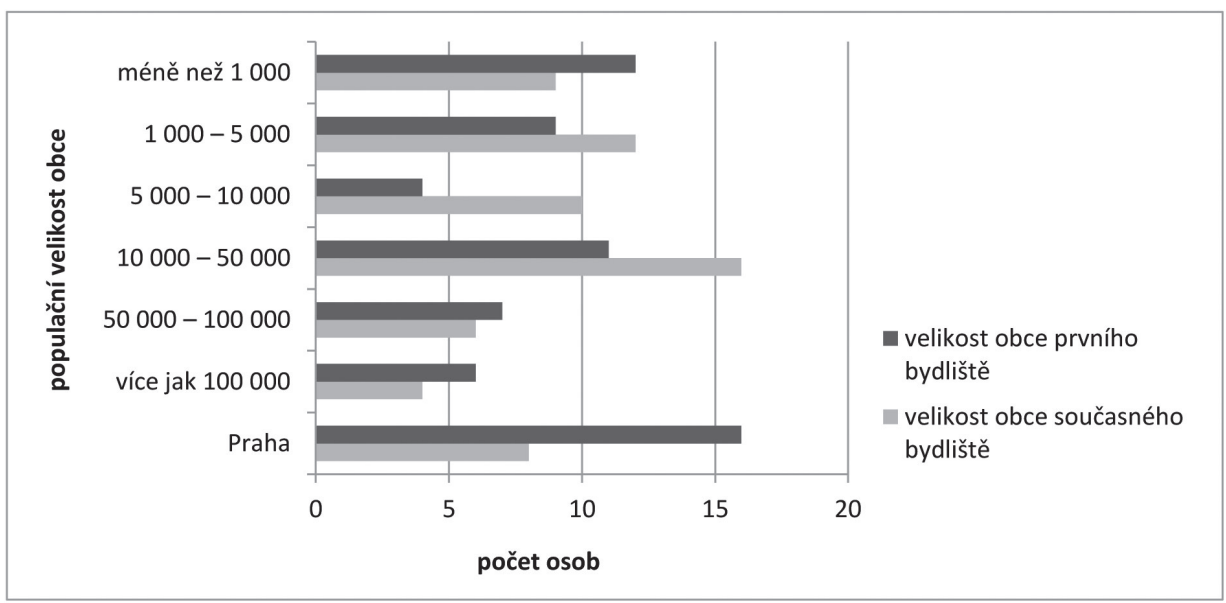

\section{Závěr}

V Česku může odhadem žít až 3000 českých krajanů z Rumunska, kteří se do země přestěhovali po roce 1989. Jejich přesídlení je od prvních úvah o odchodu až po usazení se v Česku významně ovlivněno zejména sdílenými narativy diaspory o zemi předků jako domově, historickými pokusy minulých generací o návrat, migračními sítěmi a především transnacionálními praktikami, nebot právě ony nabývají v př́padě české diaspory z rumunského Banátu mnoha podob. Vedle obvyklých transnacionálních praktik (návštěvy př́ibuzných v Česku/ v Rumunsku) či pravidelného kontaktu s příbuznými pomocí internetu a pošty, vedle dovozu zboží a produktů oběma směry nebo remitencí je banátská krajanská komunita vystavena i transnacionálním vazbám institucionalizované povahy. Na úrovni veřejného sektoru jde především o oficiální partnerství českých obcí v Rumunsku a v Česku, oficiální rozvojovou pomoc financovanou z českého státního rozpočtu a podporu v oblasti základního vzdělávání a duchovního života. Mimo to však mají obyvatelé vesnic kontakt i s českými turisty, novináři, výzkumníky, neziskovými organizacemi, umělci atd. Vlivem všech těchto aktivit a praktik je život v šesti českých vesnicích - Bígru, Eibentálu, Gerníku, Rovensku, Svaté Heleně a Šumici - životem transnacionální komunity.

Transnacionální vazby jsou projevem velmi silného propojení mezi diasporou banátských Čechů a Českem, které se promítá také do sdílených narativů a diasporického vědomí Česka jako domova (či alternativního domova). Stávají se impulsem k odchodu a usídlení v Česku. Jak dokládá výzkum, většina porevolučních příchozích během přesídlení využila právě tyto vazby a migrační sítě, které jim významně pomohly v hledání ubytování a práce a při prvotní orientaci v prostředí. 
Na jedné straně transnacionální vazby a praktiky podněcují české krajany k migraci do země, která je vnímána jako domov předků, kde se mohou cítit „jako doma“, kde mají své kořeny. Výzkum však přináší důkazy rovněž o tom, že migrace českých krajanů do Česka, o které je ve veřejném diskurzu často pojednáváno jako o „návratu“ českých krajanů, představuje pro mnoho těchto migrantů jakousi revizi vlastní identity. Zatímco v Rumunsku se považovali spíše za Čechy, v Česku - v důsledku přímého kontaktu s českou společností, kterou vnímají jako jinou, resp. sebe vnímají jako odlišné - se začínají označovat jako rumunští Češi. Toto veřejné přiznání se k rumunskosti však banátské krajany neodrazuje od snahy po nabývání českého státního občanství, ba naopak. Nicméně v kontextu dualit „doma a v cizině“ či „být domácím a cizím“ se ukazuje, že není zcela výstižné o těchto migrantech hovořit jako o navrátilcích, ale ani jako o první migrační generaci rumunských Čechů. Diasporická minulost a přítomnost, zděděná kolektivní pamět́ a vnitřní sebeidentifikace s češstvím i rumunstvím - tj. být Čechem s rumunským původem - z těchto osob dělá spíše jakési kontradiasporické migranty, kteří uzavírají kruh života diaspory v exilu. Nicméně jejich četné kontakty s Rumunskem naznačují, že Rumunsko je a bude pro tuto migrační generaci emocionální záležitostí. Odpovídají tomu i strategie jejich adaptace v Česku, kde dávají přednost malým obcím či městům, v nichž jsou životní podmínky bližší životu v Rumunsku.

Většina přesídlenců, kteří přišli do Česka po roce 1989, je nyní v ekonomicky produktivním věku. Zároveň většina z nich přijala české státní občanství. Při budoucím výzkumu rumunských Čechů by proto bylo zajímavé zaměřit se na migrační strategie generace kontradiasporických migrantů v té fázi jejich života, kdy vstoupí do seniorského věku, ale také na vztahy a identity jejich potomků, kteří se již narodili v Česku.

\section{Duben 2016}

\section{Literatura a internetové zdroje}

Bruneau, Michel. 2010. Diasporas, transnational spaces and communities. In: Bauböck, Reiner - Faist, Thomas (eds.): Diaspora and Transnationalism: Concepts, Theories and Methods. Amsterdam: Uamsterdam University Press: 167-184.

Castles, Stephen. 2004. The factors that make and unmake migration policies. International Migration Review 28, 3: 852-884.

De Jong, Gordon F. - Fawcett, James T. 1981. Motivations for migration: an assessment and a value-expectancy research model“. In: De Jong, Gordon F. - Gardner, Robert W. - Migration Decision Making. Multidisciplinary Approaches to Microlevel Studies in Developed and Developing Countries. New York: Pergamon Press: 13-58. Eisenbruk, Vladimír. 2009. Krajanská komunita ve světě a její podpora ze strany Ministerstva zahraničních věcí ČR. Krajané a Česká republika - hledání možností k nové otevřené spolupráci. Praha: 9-14. 
Fortier, Anne-Marie. 2000. Migrant Belongings: Memory, Space, Identity. Berg 3PL, Oxford.

Glick Schiller, Nina - Basch, Linda - Blanc-Szanton, Cristina. 1995. From Immigrant to Transmigrant: Theorizing Transnational Migration. Anthropological Quarterly 68, 1: 48-63.

Hanus, Lukáš. 2009. "Nové diaspory" - diaspora jako transnacionální moment. AntropoWEBZIN 4, 2-3: 13-17.

Hanus, Lukáš. 2011. Přechod české krajanské komunity z obce Gerník (Rumunsko) do transnacionálního momentu. In: Budilová, L. J. - Fatková, G. - Hanus, L. - Jakoubek, M. - Pavlásek, M.: Balkán a migrace - Na křižovatce antropologických perspektiv. Praha: AntropoWeb: 61-89.

Heroldová, Iva. 1983. Čeští reemigranti z rumunského Banátu. Český lid 70: 240-244.

Hirt, Tomáš - Jakoubek, Marek. 2005. Idea krajanského hnutí ve světle konstruktivistického pojetí národa: proměny kolektivní identity vojvodské náboženské obce. Český lid 92: 337-366.

Jakoubek, Marek. 2010. Sesek

- zapomenutá česká obec

v Bulharsku. Český lid 97: 35-50.

Jech, Jaromír. 1996. Tady byl samej les. Nadlak: Vydavatel'stvo kultúrnej a vedeckej spoločnosti Ivana Kraska.

Jech, Jaromír - Secká, Milena - Scheufler, Vladimír - Skalníková, Olga. 1992. České vesnice v rumunském Banátě. Praha: Ústav pro etnografii a folkloristiku ČSAV.

Kázecký, Stanislav. 2014. Pohled Ministerstva zahraničních věcí České republiky na problematiku českých krajanských komunit v zahraničí. In: Brouček, Stanislav - Grulich, Tomáš (eds.): Nová emigrace z České republiky po roce 1989 a návratová politika. Praha: EÚ AV ČR a IOM: 75.

King, Russel - Christou, Anastasia. 2010. Diaspora, migration and transnationalism: Insight from the study of second-generation "returnees". In: Bauböck, Reiner - Faist, Thomas (eds.): Diaspora and Transnationalism: Concepts,
Theories and Methods. Amsterdam: Uamsterdam University Press: 167-184. Kokaisl, Petr a kolektiv. 2009. Krajané: Po stopách Čechů ve východní Evropě. Praha: Za hranice: Společnost pro rozvojovou spolupráci při Provozně ekonomické fakultě ČZU v Praze.

Korostenski, Jiří - Pána, Lubomír. 2011. Dvojí adaptace volyňských Čechů na jihu Čech. In: Moravcová, Dana - Moravcová, Mirjam (eds.): Etnické komunity: integrace, identita. Praha: Fakulta humanitních studií Univerzity Karlovy v Praze: 85-100.

Kotrbatá, Ivana. 2010. „Ještě je 400 míst volných v tachovském okrese!" Příspěvek k "malým dějinám" reemigrace a dosídlení Tachovska v narativních interview na začátku 21. století. Český lid 97: 265-280. Kresl, Zdeněk. 2012. Srovnání českých obcí Svatá Helena a Rovensko v rumunském Banátu. Bakalářská práce. Praha: Přírodovědecká fakulta Univerzity Karlovy v Praze.

Kušniráková, Tereza - Čižinský, Pavel. 2011. Dvacet let české migrační politiky: Liberální, restriktivní, anebo ještě jiná? Geografie 116: 497-517.

Massey, Douglas S. 1988. Economic development and international migration in comparative perspective". Population and Development Review 14, 3: 383-413.

Massey, Douglas S. - Arango, Joaquin - Hugo, Graeme - Kouaouci, Ali Pelle-grino, Adela - Taylor, Edward J. 1993. Theories on international migration. A review and appraisal. Population and development review 19, 3: 431-466.

Nešpor, Zdeněk. 2002. Reemigranti a jejich sociálně sdílené hodnoty prolegomena $\mathrm{k}$ sociologickému studiu českých emigračních procesů 20. století se zvláštním zřetelem k západní reemigraci 90. let. Praha: Sociologický ústav Akademie věd České republiky.

Pavlásek, Michal. 2010. Př́ípad Svatá Helena. (Re)interpretace náboženských dějin české obce v Rumunsku. Český lid 97: 363-382. 
Pavlásek, Michal. 2011. Meziválečná krajanská péče jako „záchranná“ akce: k utváření kolektivní identity českých evangelíků v jihovýchodní Evropě. Český lid 98: 113-134.

Pavlásek, Michal. 2013. Clopodia česky zvaná Klopotín. Zapomenutá moravská kolonizace Banátu v multilokálním etnografickém bádání. Český lid 100: 150-172.

Salzmann, Zdeněk. 1983. Two contributions to the study of Czechs and Slovaks settled in Romania. University of Massachusetts at Amherst: Amherst.

Secká, Milena. 1998. Poválečné změny ve svatebním obřadu u Čechů v rumunském Banátě a u reemigrantů na chebsku a znojemsku. Český lid 75: 162-169.

Secká, Milena. 1996. Češi v rumunském Banátu. Češi v cizině 9: 96-104.
Sobotka, Přemysl. 2014. Češi žijící v zahraničí jsou součástí národní identity. In: Brouček, Stanislav - Grulich, Tomáš (eds.): Nová emigrace z České republiky po roce 1989 a návratová politika. Praha: EÚ AV ČR a IOM: 10. Stark, Oded - Bloom, David E. 1985. The new economics of labor migration. The American Economic Review 75, 2: 173-178.

Stark, Oded - Taylor, Edward. J. 1989. Relative deprivation and international migration. Demography 26, 1: 1-14. Vaculík, Jaroslav. 2003. Poválečná reemigrace a usidlování zahraničních krajanů. Český lid 90: 310-313.

Vaculík, Jaroslav. 2009. České menšiny v Evropě a ve světě. Praha: Libri. 